\title{
Medicine on Trial: Regulating the Health Professions in Later Medieval England ${ }^{*}$
}

\section{Sara M. Butler}

Given the hurdles one faced in trying to stay healthy in later medieval England, it should come as no surprise that the medieval English placed a premium on competent medicine. As Carole Rawcliffe has argued, "medieval life was beset by constant threats to health arising from poor diet (at both ends of the social spectrum), low levels of hygiene, high rates of infant mortality, the risks of childbirth and repeated pregnancies, accidents and injuries."1 Add to this the episodic dangers of war, epidemics, and famine, as well as the lack of antibiotics, and we have a world in great need of medical expertise. Because of the prohibitive cost of professional medicine, men and women in late medieval England insisted that medical practitioners be held to high standards. Swindlers and frauds who posed as physicians but had no real medical credentials felt the full wrath of medieval society. One of the best-known, and most revealing, cases is that of Roger Clerk of Wandsworth, indicted before the mayor's court of London in May of $1382 .{ }^{2}$ Claiming that "he was experienced and skilled in the art of medicine" when really he "knew nothing of either of the arts [of medicine and surgery] nor understood anything of letters," Clerk undertook to

* This research was funded by a grant from the Loyola University New Orleans Committee on Grants and Research. Thanks also to Florilegium's anonymous reviewers and the editors for their helpful remarks. For the purposes of this paper, I have modernized all spelling and inserted punctuation where appropriate.

1 Rawcliffe, Medicine and Society, 3.

2 This case is drawn from Riley, ed., Memorials of London and London Life, 464-66 (for the year 1382). 
cure Johanna, wife of Roger atte Hacche of London, of "certain bodily infirmities." After receiving a payment of $12 d$, Clerk gave Johanna's husband "an old parchment, cut or scratched across, being the leaf of a certain book, and rolled it up in a piece of cloth of gold, asserting that it would be very good for the fever and ailments of the said Johanna." The talisman did nothing for Johanna. Feeling deceived, Hacche took Clerk to court. The parchment itself was entered into evidence before the mayor and aldermen of the city. When asked to read the words on the parchment, the illiterate Clerk responded, "Anima Christi, sanctifica me; corpus Christi, salva me; in isanguis Christi, nebria me; cum bonus Christus tu, lava me."3 But officials examining the parchment found none of these words inscribed thereon, and the court concluded that Roger Clerk was both an infidel and a fraud. As punishment, he was to be "led through the middle of the City, with trumpets and pipes, [...] the said parchment and a whetstone, for his lies, being hung about his neck, an urinal also being hung before him, and another urinal on his back." The public display with urine flasks symbolizing the medical profession ${ }^{4}$ adorning the culprit's neck was intended to mock him. Public ridicule of this nature was a popular approach to dealing with sinners and miscreants in late medieval England; the courts intended the public punishment to act both as humiliation and as a deterrent to others who might contemplate engaging in the same fraudulent activities. ${ }^{5}$ That the court regarded Clerk's attempts to heal his patient with an old talisman as heresy demonstrates just how reprehensible his actions were thought to be. The very public and degrading punishment of Roger Clerk indicates a low tolerance for deception in the business of medicine in later medieval England.

Clerk's prosecution is significant in large part because it represents an instance in which patients advocated for their rights to adequate health care in the absence of governmental or even guild regulation of medical practitioners. Medical practice in England functioned largely without regulation until the fifteenth century. The king's sole foray into medical regulation occurred in 1421 in response to a petition by London physicians who lamented the "uncunning and unapproved" practice

3 "Soul of Christ, sanctify me; body of Christ, save me; blood of Christ, drench me; as thou art good Christ, baptize me" (my translation).

4 Uroscopy, known as "the judgement of urines" in the Middle Ages, was central to medieval medicine; see Wallis, "Signs and Senses," 276.

5 For the nature of punishments meted out by ecclesiastical courts, see Finch, "The Disciplining of the Laity." 
of empirics and women. ${ }^{6}$ Henry $\mathrm{V}$ approved a licensing process permitting only university-trained practitioners to serve the public. Nonetheless, as Carole Rawcliffe has observed, this model was "doomed to failure"; the small numbers of university graduates in medicine were simply no match for England's sick. ${ }^{7}$ Guilds played a far more active role in attempting to regulate the practice of medicine. However, the nature of supervision that emerged from the College of Physicians and London's Company of Barber-Surgeons (later emulated in other cities across England) had more to do with driving off the competition than ensuring the health of the people. ${ }^{8}$

In this void, much of the impetus to regulate the medical profession was left to the people themselves. Patients were not without recourse: English common law provided a potent weapon in the form of breach of contract suits. Disgruntled patients regularly turned to the courts to prosecute incompetent practitioners from all ranks of the profession. As a charlatan and certainly a practitioner of lower rank, Clerk represents one end of the professional continuum, but legal complaints revolving around the quality of medical treatment also frequently targeted those from the other end of the spectrum - legitimate medical practitioners of good social standing. The overwhelming majority of the cases involving contracts with medical practitioners can be assigned to two categories, namely, complaints by patients about service and complaints by practitioners about the non-payment for services. These two categories are interconnected. When a medical practitioner objected to the courts that he had not been paid for his work, more often than not the patient's response was that he or she did not pay the medical practitioner because he had not lived up to his side of the bargain. While most contracts of the time were oral, their particulars are nonetheless revealed in the lawsuits. ${ }^{9}$ Unlike today's physicians, medieval practitioners employed on an ad hoc basis regularly covenanted to cure the patient, not simply to treat the illness to the best of their abilities. Consequently, when the illness persisted or a new complication developed or, worse, when the patient died, the practitioner received no compensation for his labour, nor did the patient reimburse him for his expenses. It is difficult to understand why medical professionals undermined their

6 Strachy et al, eds., Rotuli Parliamentorum, 4:158.

7 Rawcliffe, Medicine and Society, 120.

8 Theilmann, “The Regulation of Public Health," 206-207.

9 While some existing lawsuits refer to written obligations, this study could not uncover any surviving evidence of this kind. The oral nature of medical contracts continued well into the early modern period; see Pelling, Medical Conflicts, 254. 
own credibility and risked losing their wages by making everything contingent on a cure. Salaried physicians, as opposed to those hired to treat a specific condition, did not favour this approach and actively fought against it; as Roger French has noted, "The physician on a [long-term] contract did not legally promise to cure the diseases afflicting his patients, but to be diligent in his advice and his visiting, to let blood prophylactically at the appropriate time of year and to be on hand when epidemics arrived." ${ }^{10}$ Given the drawbacks for medical practitioners, that short-term contracts regularly promised to heal reveals the critical role played by the market in determining the nature of these contracts. Patients focused on the end goal, not the process. They did not care about treatment, they wanted a cure, and they were not willing to engage the (admittedly costly) services of a practitioner without a contract that stipulated just that. The nature of the contracts, then, illuminates the patients' agency and their determination to receive quality service.

The goal of this paper is to underscore the tenacity of English patients in their quest for reliable health care by examining instances of medical practitioners at law in matters relevant to contractual agreements concerning the practice of medicine. These cases also reveal some of the obstacles faced by patients in this process: primarily, patient demands were out of step with the practical realities of medical care. Patients articulated their discontent with two aspects of medical practice: they believed that medical care cost more than it was worth, and they wanted guarantees for recovery, but even though medical practitioners were often willing to enter into a contract for a cure, these guarantees were ultimately just empty promises.

With its principal focus on daily practice, this study of these disputes provides an account of the interaction between medical practitioners and their patients, the kinds of contracts they drafted, and the approach adopted by the courts when confronted with lawsuits relating to these contracts. Given the paucity of case studies surviving from the period's medical literature, an intimate view of medicine in practice is needed. ${ }^{11}$ Historians have traditionally relied on medical treatises for insight into the world of medieval medicine, and because some working surgeons or physicians, in fact, wrote such treatises, the practice of medicine has not remained wholly obscure.

10 French, Medicine before Science, 120-21.

11 As Esther Cohen has noted, existing case histories are "very often generalized and impersonal; the cases (whose reality is doubtful) are often merely an excuse to write an opinion concerning the treatment of specific diseases"; E. Cohen, "The Expression of Pain," 203 n. 21. 
Treatises by John Arderne or Thomas Fayreford, both fourteenth-century English surgeons whose patients and their treatments formed the nucleus of their works, supply some insight into the daily practice of medieval medicine. A study of medical practitioners at law, however, offers a very different perspective altogether: lawsuits permit a closer look into the relationship between practitioners and their patients and highlight the role played by patients in demanding quality care.

\section{The Sources}

Because there was no single court appropriate to address medical disputes, this investigation casts a wide net. The largest group of cases comes from municipal courts (mayors' courts, borough courts, fair courts, even guild courts). Well versed in the resolution of local financial disputes, the municipal courts were generally the first choice of medieval litigants. The equity courts (such as the court of Chancery) also played a prominent role in the resolution of disputes arising from medical cases, but it is worth noting that many of the complainants were appealing to Chancery because they expected to lose their suits in the municipal courts. The court of Chancery existed as both a court of appeal and as a venue for cases without remedy by common law, such as some of the more unusual cases relating to the newly professionalized field of medicine. ${ }^{12}$ Because of the nature of the contract between patient and medical practitioner, the king's courts, specifically King's Bench and Common Bench, both of which were popular venues for trespass litigation, were also ideal fora. ${ }^{13}$ Most lawsuits against medical practitioners alleged breach of contract, citing three distinct problems: non-feasance (where the medical practitioner did not perform his side of the contract), misfeasance (where the medical practitioner did perform his side of the contract, but did it badly), or iatrogenic sequelae (where the treatment caused a new

12 The court of Chancery developed in the mid-fourteenth century in response to the rigid and inflexible system of common law. Chancery existed precisely for those cases without a specific remedy at common law. For more information on the rise of the court of Chancery, see Tucker, "The Early History of the Court of Chancery."

13 Trespass is the medieval equivalent of tort. King's Bench and Common Bench (also known as the Court of Common Pleas) had overlapping jurisdictions. Common Bench was England's central venue for civil litigation. King's Bench addressed a mixture of civil and criminal cases, but it was the second most popular forum for trespass litigation. For further information, see Hastings, The Court of Common Pleas, chap. 2, and Blatcher, The Court of King's Bench. 
condition or injury)..$^{14}$ Because of the overwhelming abundance of documentation surviving for the king's courts, this study relies in part on the selection of medical trespass litigation that appears in the appendices to Robert Palmer's English Law in the Age of the Black Death, 1348-1381. ${ }^{15}$ Finally, because most of the cases in this group have no recorded verdicts, this investigation also employs the patent rolls and close rolls, both of which include the king's correspondence and thus offer some sense of royal action.

These cases are not geographically representative of all English society, less as a result of the methodology of this study than because of the nature of the medical profession. University-trained medical practitioners, as well as those working within the guilds, operated in towns and cities; rural medicine seems not to have required written documentation and thus still remains much of a mystery to historians. Accordingly, urban environments - particularly London, York, Colchester, and Norwich - feature prominently in this investigation. Chronologically, this study rejects the artificial divide imposed by historians on the era in which 1485 (the beginning of the reign of Henry VII) is traditionally regarded as the end of the Middle Ages, preferring instead to conclude directly prior to the English Reformation. Thus, the cases span the period from the late thirteenth to the early sixteenth century.

In the last thirty years, social historians have become increasingly aware of the value of studying law in practice to gain a clearer understanding of social behaviours. In terms of medical practitioners at law, a study of the intimate connection between law and real social values reveals much about contemporary attitudes towards medicine and its practitioners. Granted, the legal records reflect only a limited segment of the medical care available: patients who could afford to engage medical practitioners and, in some cases, to take them to court were financially comfortable, whereas the services of medical practitioners generally were beyond the means of the poor, who were more likely to turn to home remedies and miracle cures; indeed, healing shrines, frequented by both the rich and the poor, were an astonishingly lucrative business in the Middle Ages. Thus, although the records are not fully representative of the broad spectrum of approaches to medical care, they offer a good indication of the array of the services provided by trained medical professionals and of the needs of the people who employed them.

14 Cosman, "Medieval Medical Malpractice," 22.

15 Palmer, English Law in the Age of the Black Death, appendices 6 and 7, pp. 340-49. 


\section{The Lawsuits}

Wary of paying exorbitant prices for substandard health care, patients were willing to engage the services of a medical practitioner only if they could enter into contracts promising specifically to cure the condition. For a medical practitioner, the drawbacks of contracts of this nature are obvious; yet, for a patient, the disadvantages were actually much greater. Anxious about litigation, medical practitioners who survived on short-term contracts commonly refused to enter into agreements if they believed the patient was incurable. The English surgeon John Arderne (1307-1377), whose treatises were widely read in the late-fourteenth and fifteenth centuries, advised specifically that surgeons should not take on patients with little hope of survival; and above all, surgeons "should always consider where their fee was coming from."16 Some medical practitioners were capable of rising above such a legalistic approach to medicine, but they sometimes also went unpaid. The case of a Dutch friar working out of the house of the Greyfriars in London in the late 1470s illustrates the dangers of working without a contract. In his bill to the chancellor, Friar Eryk de Vedica explained that when Alice wife of William Stede of London sought him out to cure her of her disease, he flatly refused: not only was she "a woman of great age," but she suffered from "a great disease and sickness of swelling in her body and also so great a disease in her limbs that a great part of the flesh of her legs was rotten away." ${ }^{\prime 7}$ In spite of his sense that she was beyond help he agreed, at the pleading of her friends, to ease her pain but declined to enter into a written obligation to cure her. He "waited upon her daily by the space of five weeks and more ministering unto her good and wholesome medicines." At the end of that time, Alice felt so "amended in her body" that she thanked him for his diligence, gave him 20s for his labour, and sent him on his way; he soon found himself cited to appear before the sheriffs of London, discovering that Alice's husband had not "licensed his said wife for to give the said money," and he wanted it back. Because of the legal doctrine of coverture that regarded husband and wife as one person under the law represented by the husband, without a formal contract with her husband, Friar Eryk had no legal recourse. A similar situation arose in the case of William Parouns, also a London physician contemporary with Friar Eryk. William Robynson, who was "sore sick of the infirmity of pestilence," hoped

16 Theilmann, “The Regulation of Public Health," 206 and 220 n. 4, citing Arderne, Treatises of Fistula in Ano, 5-6.

17 TNA PRO C 1/66/397 (c.1475-80). 
to enter into a contract with Parouns; Parouns declined. Like Friar Eryk before him, Parouns would not sign a written contract, but he did work to help Robynson. Once recovered, his patient refused to pay him for either his labour or the 20s worth of medicines, and without a written obligation (that is, a contract), Parouns had no remedy at the common law. ${ }^{18}$ The fates of both Friar Eryk and William Parouns confirm that working without a contract was an unwise undertaking; from a business perspective (although certainly not a moral one), both would have been better off if they had denied the patients treatment and simply left them to die.

At least one medical practitioner attempted to work around the restrictions imposed by a system that focused so heavily on the outcome of the treatment. In doing so, he inadvertently forayed into the world of 'malpractice insurance.' In the year 1393-94, the barber-surgeon John de Cartmell approached a colleague, John Catlew of York, to perform an operation for the removal of a (kidney?) stone. Catlew agreed to do the operation; however, his agreement hinged on the condition that Cartmell's wife, Alice, take an oath before the mayor of York promising not to press charges against Catlew if the operation was unsuccessful. ${ }^{19}$ Knowing the risks of such an operation, no reputable barber-surgeon would take on such a case without some guarantee of protection from the law. ${ }^{20}$ Without that oath, Cartmell would have had to resort to the services of an expert in stone-cutting, a craftsman much lower down on the medical professional pyramid who moonlighted in medicine, but whose primary occupation was probably something else altogether. ${ }^{21}$ Because of the danger involved in the operation, Cartmell preferred to place his trust in a fellow barbersurgeon. Catlew's insistence on a formal oath stands out as an early recognition of the need for legal protection. Not long after this lawsuit, medieval municipalities also came to understand the need to protect medical practitioners in the event of a patient's death. Following the lead of the London barber-surgeons in the year 1416, urban centres across England formulated ordinances requiring medical practitioners who undertook to treat patients "in peril of death or of maiming" to appear within

18 TNA C $1 / 105 / 35$ (c.1486-93).

19 Recorded in the Corporation House Book of York for 23 January 1393-94, cited in Auden, "The Gild of Barber Surgeons," 1400.

20 As Philip Stell has noted, cutting for the stone was a dangerous operation: Frere Jacques cut six boys for the stone in the Hotel Dieu in seventeenth-century Paris, and all six died; see Stell, Medical Practice in Medieval York, 26.

21 Harrison, Disease and the Modern World, 19. 
three days of the contract to present the patient to city-appointed medical officials for inspection. ${ }^{22}$

Patients focused not only on receiving quality care but also on the expense of that care. In many disputes over breach of contract, it is clear that the patient believed that the fee for a practitioner's services was excessive. Because most legal records are quite brief, sometimes a historian needs to read between the lines to uncover a patient's motivations. For example, a case drawn from the Colchester borough courts of 1360 demonstrates the typical brevity of a record, while also revealing a patient determined not to be exploited. William Lache complained that Robert Wreighte hired him for $12 d$ to cure Robert of his wound and attend on him; Robert replied that although his wound was indeed cured, he did not receive proper attention and therefore was unwilling to pay Lache his wages. ${ }^{23}$ Sometimes patients clearly articulated that the practitioner's charges were unwarranted and refused to pay them on principle. Gilbert Humfreyson of Hungerford, in Berkshire, a "horsekeeper" for Earl Rivers in the years 1464-1465, expressed that belief in a letter to his employer when complaining of John Isyng, surgeon. ${ }^{24}$ He hired Isyng to treat an injury to his hand but was appalled when Isyng charged him 20 nobles for the cure. Moreover, as Humfreyson remarked, Isyng had done little to help: his hand was "utterly maimed." When Humfreyson would not pay Isyng for his services, Isyng resorted to slander, spreading the rumour that Humfreyson had stolen one of Earl Rivers's horses. The story landed Humfreyson in court before the constable's ward of Newbury for horse thievery; his letter to the earl was to beg his assistance in obtaining an acquittal. It is unlikely that a man in Humfreyson's position could have scraped together 20 nobles. ${ }^{25}$

22 Young, comp., The Annals of the Barber-Surgeons, 42. An example of the oath surgeons had to take to this effect is available in the case of John Severelle Love, a London surgeon, who gave security in 1417, promising that if he should "take any man under his care, as to whom risk of maiming, or of his life, might ensue, and within four days should not warn the Wardens of the craft of Surgery thereof, then such recognizance [ $£ 20$ sterling] should hold good”; see Riley, ed., Memorials of London and London Life, 651.

23 Jeayes, ed. \& trans., Court Rolls of the Borough of Colchester, 2:120 (for the year 1360).

24 TNA PRO E 315/486, m. 10 (c.1464-65).

25 A "noble" was a gold coin introduced by King Edward III; see Frey, Dictionary of Numismatic Names, 160, s.v. noble. In the year 1464 , one noble was worth $8 s 4 d$; thus, 20 nobles was worth $£ 8$

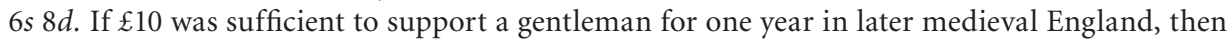
this horsekeeper was clearly in trouble. See also Dyer, Standards of Living, 31-32. 
The case of John Isyng is instructive: it raises the question how frequently medical practitioners, faced with their patients' refusal to pay, struck back by working outside the law in order to gain payment for their services. Given the popularity of non-payment suits pleaded against patients, it is not surprising that some anxious medical practitioners found alternative means to pry their wages out of their clients' tight fists, rather than awaiting the results of a cumbersome and lengthy court proceeding. Among the lawsuits, Isyng's gossip mongering was not the only evidence of what legal historians refer to as "self-help." ${ }^{26}$ John of Cornhill allegedly robbed his patient's home, stealing a blanket, two sheets, and a supertunic worth 20s, when Alice of Stockynge neglected to pay him for treating an infirmity of the feet, her condition having worsened after his treatment. ${ }^{27}$

In order to justify non-payment for services rendered, Gilbert Humfreyson declared that John Isyng had failed to cure his hand. Some patients may have fabricated allegations of unsuccessful or even botched treatments precisely to get out of paying fees that they believed to be exorbitant. Other patients, instead, challenged the business practices of their medical practitioners, accusing them of inflating their costs by misrepresenting the seriousness of an injury. A fine example of this tactic appears in a Chancery file dating to the years 1467-1471 concerning a lawsuit between Nicholas Wodehill, surgeon, and William Chapman, gentleman. In hopes of obtaining payment for his labour, Wodehill submitted an invoice listing all of his services for Chapman and his family over a four-year period, including their dates and costs. Chapman's rejoinder addresses each service listed in the invoice, stating that Wodehill had distorted the injury and noting what he thought the treatment was really worth. Wodehill claimed he cured Chapman's hand when a pin punctured the sinew of his index finger, a treatment Wodehill deemed worth 40 s. Chapman's version states that an imbalance of the humours caused his hand to swell, necessitating a treatment valued at $3 d$. Similarly, Wodehill contended that Chapman's son Robert grievously hurt his left hip and leg when he fell down the stairs, so that it was "sore bruised, wasted and consumed" and Robert "might not stand nor go" and was "likely to have been maimed" - the cure was worth 5 marks. In Chapman's account, Robert had only "a little boil" on his hip — for a cure worth $1 d .{ }^{28}$ With two such radically

26 Harding, Medieval Law, 33, 68, and 97.

27 Talbot and Hammond, The Medical Practitioners in Medieval England, 137, citing Cal. of Sheriffs Court Rolls, Miscellaneous Roll CC, m. 17d (for the year 1320).

28 TNA PRO C 1/1489/102-105 (c.1467-71). 
different stories (and fees!), who is to be believed? At the very least, the dispute between Wodehill and Chapman exhibits a sizeable gap in perceptions of the value of medical services as understood by the suppliers and consumers.

Here, it is worth pointing out that a medical practitioner's expenses might be considerable. The medicines alone were dear. When William Wotton hired Richard Smyth, doctor of physic, to cure him of mala mortuum [sic] (a disease of the feet and shins), ${ }^{29}$ Smyth claimed to have administered "wholesome medicines" worth 40 s, fortunately with great success. ${ }^{30}$ John Broman was indebted $13 s 8 d$ for medicines he bought on credit from Emma Plomer of Colchester (but for which he apparently never paid). ${ }^{31}$ Although these costs may sound exorbitant, they most likely reflect a large quantity of medicines consumed over an extended period. Spices like pepper, cumin, ginger, and saffron were some of the most common ingredients in basic medicines and they were expensive. ${ }^{32}$ According to a spicer's bill of debt, pleaded at the borough court of Nottingham in 1436, half a pound of pepper cost $14 d$, half a pound of cumin cost $2 d$, a quarter of a pound of ginger was $61 / 2 d$, and an ounce of saffron was $12 d . .^{33}$ More exotic ingredients were even more costly. Medicines, in all their forms, whether syrups, electuaries, plasters, theriacs, enemas, or pills, were compounds prepared by apothecaries and involved a great number and quantity of ingredients. In his study of the medieval spice trade, Paul Freedman notes that the most celebrated theriac (thought to be an antidote to poison) "contained no fewer than eighty-three ingredients, mostly aromatic exotics." ${ }^{44}$ While some medicines were probably nothing more than placebos, scores of others were effective. ${ }^{35}$ The wide variety of ingredients, however, meant that medicines were "elaborate and expensive ways to relieve routine complaints." 36 Nonetheless, the administering of drugs was the foundation of medieval medicine and, largely, what patients expected of their medical practitioners. ${ }^{37}$ Pharmaceuticals were the product that made medicine tangible for consumers.

29 Du Cange, Glossarium mediae et infimae latinitatis, s.v. malum-mortuum.

30 TNA PRO C 1/578/47 (c.1518-29).

31 Jeayes, ed. \& trans., Court Rolls of the Borough of Colchester, 3:125 (for the year 1377).

32 See Freedman, Out of the East, chap. 2, "Medicine: Spices as Drugs."

33 See Stevenson, ed., Records of the Borough of Nottingham, 2:157 (for the year 1436).

34 Freedman, Out of the East, 68.

35 For example, see Riddle, "Contraception and Early Abortion." Riddle analyses the ingredients of an abortifacient, whose recipe is preserved in a manuscript dated $c .800$, to demonstrate that medieval medical practitioners had a sound understanding of herbal properties.

36 Freedman, Out of the East, 68.

37 See Theilmann, “The Regulation of Public Health,” 208. 
On top of the steep costs of medicines, it seems clear that contracts were exclusive; patients expected practitioners to abandon all other clients and dedicate their time and labour for however long it took to heal the ailment. Friar Eryk claims to have waited on his patient daily for five weeks. When Balthasar de Quarcyes, a London surgeon, contracted to cure Alexander Martyn, servant of the bishop of Ely, he insisted that his patient move into his home for a full month. (The two also negotiated a contract for bed and board. ${ }^{38}$ In trying to understand why physicians' wages might seem inflated, it is worth taking into account not only the physician's costs but also his labour.

Not all patients who appeared in court in cases of non-payment for services were challenging the high costs of medical practice; some sued because they believed their medical practitioners were negligent and needed to be held accountable for their malpractice. Typically, claims of negligence centred on failed surgical procedures. Vivian Nutton has outlined the hazardous nature of medieval surgery:

One cannot neglect the torments of those left for years with a suppurating wound after being cut for bladder-stone or the almost inevitable recurrence of an inguinal hernia. One can only shudder at the agonies of patients forcibly held (or chained) down while the surgeon plied the knife or the red-hot cautery, whose pain was only slightly dulled by draughts of opiated wine or by the soporific sponge. [...] Surgery had its drawbacks as much as physic, and it was very much a treatment of last resort. ${ }^{39}$

Given the perils of medieval surgery, the predominance of surgery-related complaints by dissatisfied patients is not surprising. Nonetheless, lawsuits relating to surgical grievances show that patients' expectations were unrealistic. Generally, they expected to be restored to health without any reminders of their earlier ailment. Peter Strug's attempt to heal William Brid's injured shin left his leg so "curved" that Brid could not walk. ${ }^{40}$ Many others allegedly sustained a loss of limbs: Richard Brown lost a leg to the supposed negligence of Thomas Ball, a surgeon from Nottingham. ${ }^{41}$ Others complained of vision loss: Agnes wife of John Ardale of Coventry asserted that she

38 TNA PRO C 1/442/28 (c.1515-18).

39 Nutton, "Medicine in Medieval Western Europe," 161.

40 TNA PRO CP 40/446, m. 153 (c.1372-74), as transcribed in Palmer, English Law in the Age of the Black Death, A7q, p. 345.

41 Stevenson, ed., Records of the Borough of Nottingham, 2:316-19 (for the year 1482). 
had lost her vision because of the "incompetence" of Robert Barbour in dealing with an eye ailment. ${ }^{42}$ It is apparent that some patients were simply wishful thinkers, burdening their medical practitioners with highly unrealistic expectations. John Arnold of Bennington, in Lincolnshire, hired Francis Percy of Nottingham to cure him of deafness. ${ }^{43}$ John son of John of Eltisley, in Cambridgeshire, contracted with Roger Barber for $9 d$ to cure his baldness. ${ }^{44}$ When Agnes wife of Robert de Stratton employed John Swanlond to heal her hand, she came to him with "her hand almost cut off, hanging by the veins and nerves." Swanlond rejoined the hand, but, much to her dismay, it later became infected and the hand was maimed.$^{45}$ None of these conditions is easily treatable even today, with twenty-first century knowledge and technology. Rather than entering into contracts to cure, these medical practitioners should have told their prospective patients that miracles are best obtained by praying at a shrine. That is not to suggest that medieval medical practitioners were incompetent; in fact, given the flawed theoretical approach that informed their work and the agonies of the experience of medieval surgery, it is striking just how successful late medieval medicine was. As Carole Rawcliffe has said of medieval field surgeons, "It is a testimony to the skill of the medieval surgeon that so many badly wounded individuals actually lived to fight again." ${ }^{36}$ Moreover, medieval surgeons devised some unexpectedly impressive procedures for notoriously difficult conditions, such as cataracts and hernias. ${ }^{47}$ And, if the records are to be believed, some physicians did perform miracles. Nicholas Alcock, barber-surgeon of London, managed to cure Peter Benett of Kent when the "calf of his right leg [was] almost cut in sunder." When Alcock arrived on the scene in Eltham, Kent, Benett "was almost dead by

42 TNA PRO CP 40/444, m. 547d, as transcribed in Palmer, English Law in the Age of the Black Death, A7p, p. 345. See also TNA PRO KB 27/449, m. 88, William de Corbrig vs. Thomas de Blythe of London (1373).

43 Stevenson, ed., Records of the Borough of Nottingham, 3:186-89 (for the year 1531).

44 Gross, ed., Select Cases Concerning the Law Merchant, 1:36 (for the year 1288).

45 TNA PRO KB 27/451, m. 114; TNA PRO KB 27/452, mm. 2d, 110d, and KB 27/453, mm. 27d, 100d (1374); as transcribed in Palmer, English Law in the Age of the Black Death, A7u, p. 346, and A7w, pp. 346-47. Much has been made of this case; see Chapman, "Stratton vs. Swanlond."

46 Rawcliffe, Medicine and Society, 72.

47 McVaugh, "Cataracts and Hernias."

48 TNA PRO REQ 2/8/62, m. 2. The Public Record Office dates this case between the years 1492 and 1547. Alcock's will is dated to 6 May 1550 (TNA PRO PROB 11/33), so it must have been written a good time before this. 
the bleeding of the said wound, and because his blood was so near spent the wound required the more cunning and diligence to keep the leg from putrefying." Alcock cured him (but Benett never paid him for his services).

Allegations of negligence suggest that some patients had legitimate concerns. Certainly, some of these reports of negligence are enough to make the modern reader squirm. For example, when Simon Barber of Lincoln undertook to cure John Bittern of a protracted illness, Simon "carelessly and improvidently cut a vein in the head of the same John." ${ }^{\prime 49}$ Bittern bled so profusely "that his life was despaired of." Barber is fortunate that Bittern was asking only for damages and was not at the same time pursuing criminal charges for assault. In fact, the most gruesome incident of health care gone awry was sued simultaneously as both breach of contract and felony assault. Thomas de Shene ${ }^{50}$ of London, a fishmonger, contracted with John le Spicer of Cornhill to treat a wound on his jaw. Dissatisfied with the result, Shene turned to the mayor's court in the year 1354. The judges sided with Shene, saying that if Spicer "had been expert in his craft or art, or had called in counsel or assistance to his aid, he might have cured the injury." ${ }^{1}$ But "through want of skill," the wound had since become incurable. Despite this success, Shene sued also in the king's court for assault. His appeal masked the case as a typical assault. Shene claimed that John le Spicer had "struck him on the shoulder on the right side of his head and there cut his veins and nerves such that the abovesaid veins and nerves were so constricted and withered that his mouth is drawn and enormously twisted and his eye is uprooted, whereby the plaintiff lost most of his vision, hearing, and speech." John le Spicer's response highlighted that he was, in fact, a physician and that the plaintiff had hired him for his services. But Shene stuck to his story: John le Spicer had "feloniously maimed him against the lord king's peace, his crown, and his dignity." 52

Thomas de Shene was not the only patient boldly to re-imagine a bungled surgery as felony. John atte Forde and Ellen his wife contended that in December 1359, the London physician William Philip "feloniously as a felon etc., treacherously and by

49 TNA PRO CP 40/494, m. 173d (for the year 1384); as transcribed in Arnold, ed., Select Cases of Trespass, 2:425-26.

50 "Shene" was the medieval name for Richmond.

51 Riley, ed., Memorials of London and London Life, 273-74 (for the year 1354).

52 Corporation of London Record Office, Letter Book G, fol. 18 (1354), as transcribed in Palmer, English Law in the Age of the Black Death, A6d, p. 341; TNA PRO KB 27/375, m. 19 (1354), as transcribed in Palmer, English Law in the Age of the Black Death, A7a, p. 342. 
premeditated assault against the lord king's peace, crown, and his dignity maimed [Ellen], whereon he fled and they followed to the four nearest wards." ${ }^{3}$ The defendant denied the allegations altogether. Rather, as a physician, he had been approached by the plaintiffs to cure Ellen of "a certain sickness dangerous and difficult to heal on her hand." He had agreed and "applied to this sickness divers cures and medicines," doing nothing to maim her. This jury also took the side of the plaintiffs, saying that William had "with a certain knife feloniously struck that Ellen across the palm of the same hand such that the same hand's veins and nerves contracted and wholly died, whereby the same Ellen totally lost the force and aid of the same hand.” The court assessed damages at $\mathfrak{E} 30$, and William Philip was arrested.

Medical practitioners often defended their actions by shifting the blame to the patient. Peter Blank, a surgeon, adopted this approach when the stationer Simon Lynde sued a plaint against him before the London sheriffs for failure to cure his child's diseased eye. ${ }^{54}$ Blank's appeal to the chancellor for assistance in the matter made it clear that he had done everything in his power to heal the child, whose eye was diseased with a "pin and a web" (probably cataracts). Lynde did not heed his instructions. Blank had ordered that the boy must be "kept from misbehaving himself with his hand in touching and rubbing of the said eye," and yet that is exactly what the child did. The failure, then, was not Blank's, but Lynde's for not following instructions. In a similar situation, in the year 1360, Richard Erdale accused John Barbour of Colchester of cutting a vein while treating Erdale for an unspecified illness; Erdale eventually lost his arm as a result. ${ }^{55}$ In the lawsuit, Barbour responded that his cure would have worked just fine if Erdale had listened to him and allowed the arm to rest until it had healed. The borough court acquitted Barbour. Walter Leche of Billingsgate also cited his patient's lack of cooperation as the reason for his failed cure. ${ }^{56}$ Thomas atte March hired Leche to cure his finger which had been "casually cut"; according to March, the cure was "so indiscreetly, negligently, or maliciously made" that he lost "a great part" of the middle finger of his right hand. Leche's response, put forward by his attorney, declared that March "would do nothing that

53 TNA PRO KB 27/399, m. 71d (1360), as transcribed in Palmer, English Law in the Age of the Black Death, A7c, pp. 342-43.

54 TNA PRO C $1 / 187 / 89$ (c.1493-1500).

55 Jeayes, ed. \& trans., Court Rolls of the Borough of Colchester, 2:117 (for the year 1360).

56 TNA PRO KB 27/434, m. 53d (1369), as transcribed in Palmer, English Law in the Age of the Black Death, A7k, p. 344. 
would better the wound." Even more damaging, the day after Leche applied his cure, March returned with a hatchet and proceeded to beat Leche. Ironically, in the process, March re-injured his finger: he "broke his finger and pulled the bones, nerves, and veins of that finger so much with a pair of pinchers that he caused the damage on himself." Finally, Matthew Rutherford, a York physician, also defended a suit for failure to cure by pleading that his patient, "in defiance of his orders, had insisted on eating unwholesome food, and furthermore, had thrown away his medicines." ${ }^{\prime 7}$ If a patient refused to listen to the learned advice of his medical practitioner, not only was he in breach of contract, but the responsibility for the worsened condition fell squarely on the patient's shoulders.

The yawning gap in medical knowledge between practitioner and patient, and the inability of the practitioner to articulate that information in plain terms, led to some frustration among patients. As one London surgeon implied, his patient simply did not understand how the body works. When Balthasar de Quarcyes undertook to cure Alexander Martyn of "diverse infirmities diseases and sicknesses which he then had resting in his body," Quarcyes addressed most of Martyn's concerns but "left a little issue to be running in one of his legs," which he explained was necessary "for preservation of his life." ${ }^{58}$ Probably much like today's reader, Martyn could not see how that bothersome "little issue" in his leg was keeping him alive, and thus was suing Quarcyes for debt before the sheriffs of London. Another medical practitioner spent most of his time arguing with his patient over the diagnosis. John Clotes of Bemelond hired the leech John Luter, to cure him of a skin disease called "salsefleume"; 59 however, the leech was convinced that Clotes was actually suffering from leprosy, even though Clotes denied it. Luter agreed to cure Clotes only "so long as he was not leprous, and the plaintiff assured him that he was not leprous." ${ }^{60}$ When Luter's cure failed to have any effect, Clotes took him to the mayor's court: the mayor judged that Luter had taken wages "fraudulently, deceptively and injuriously."

57 Talbot and Hammond, The Medical Practitioners in Medieval England, 213-14, citing Edwards, The Early History of the North Riding, 161.

58 TNA PRO C 1/438/1 (c.1515-18). This dispute is also addressed in TNA PRO C 1/442/28 by Peter Starky, citizen and draper of London. In this bill, Starky suggests that Martyn was suffering from "the great pox."

59 "Salsefleume” was “[c] aused by 'salt', or corrupt, phlegm, which gave rise to facial symptoms similar to lepra. It ranked alongside morphew, scabies and other dermatological disorders which were deemed potentially leprous but curable"; Rawcliffe, Leprosy in Medieval England, 205-206 n. 4.

60 Thomas, ed., Calendar of the Plea and Memoranda Rolls, 3:289 (for 1408-09). 
Patients also showed confidence in questioning the appropriateness of their practitioner's choice of treatments. John Roper, a London tailor, accused Matthew Rellesford, surgeon, of using "dangerous medicine" in the treatment of an anoncomo (a boil) on his left foot: ${ }^{61}$ the corrosive salts Rellesford used had made his ailment even worse. Robert de Skyrne accused his leech, Thomas Butolf, of applying "medicines contrary to the aforesaid disease"; as a result, Skyrne was still suffering from ringworms and was "compelled to seek a cure elsewhere." ${ }^{2}$ Inappropriate use of medicines was a common allegation. Gyles Vanhuchyn argued that Antony Port, a London surgeon, "administered such contrarious medicines" that he "was much worse and more grieved" with "the great pox." ${ }^{3}$ Even prominent surgeons were not immune to this complaint: Marcellus de la More, a well-known London surgeon, stood accused of administering "medicines contrarious" to his patient's (unspecified) disease. ${ }^{64}$ That de la More eventually went on to become King Henry VIII's royal surgeon suggests that the complaint did little to harm his good name. ${ }^{65}$

In order to substantiate allegations concerning the incompetence of their practitioners, some patients, like Robert de Skyrne, claimed they sought the services of another medical practitioner to correct the damage caused by the first. Such an assertion was a useful pleading strategy in contractual litigation; if another doctor could succeed where the defendant had failed, then the court should really agree. Edmund Broke of Southampton made this kind of complaint against Nicholas Sax, a London surgeon. Broke was suffering from a fistula, a passage abnormally running either from one organ to another or to the body surface as a result of an abscess or trauma and leading to the secretion of fluids. As one might imagine, a sore of this nature was extremely difficult to treat in the medieval period; John Arderne, in fact, made a name for himself specifically by creating a workable and non-fatal treatment for fistula of a certain kind, fistula in ano, a perforation of the rectum caused by excessive time spent in the saddle. Arderne's solution to the fistula was a process of ligature and drainage, with intense pressure applied to staunch the bleeding; more

61 Talbot and Hammond, The Medical Practitioners in Medieval England, 213 (c.1443). The Oxford English Dictionary defines ancome (variant spelling of anoncomo) as "a boil, an imposthume," citing Sir Thomas Elyot's Dictionary of 1538.

62 TNA CP 40/509, m. 230 (for the year 1388), as transcribed in Baker and Milsom, eds., Sources of English Legal History, 363.

63 TNA PRO C 1/246/50 (c.1500-01).

64 TNA PRO C 1/340/53 (c.1504-10).

65 Talbot and Hammond, The Medical Practitioners in Medieval England, 207-208. 
commonly, medical practitioners simply cut open the fistula, a process that often led to severe haemorrhaging (and sometimes death). ${ }^{66}$ Broke's surgeon pursued the latter approach. According to his bill of complaint, Broke was "in jeopardy of his life" until he employed another surgeon to heal him. ${ }^{67}$ Thomas Medewe, parish priest of Aspden, Hertfordshire, also had to seek the services of another practitioner. By "God's visitation," Medewe was suffering from an infirmity of the throat, obviously an irksome affliction for a man whose career demanded that he say mass. He contracted with John Dagvyle, also a London surgeon, for a plaster for his throat. The first plaster, worth $4 d$, "relaxed well the matter in his throat" so that he was "nigh whole." ${ }^{6}$ Dagvyle offered to make him "thoroughly whole" by applying a second plaster, worth $20 d$. The more expensive medicines had a wholly different effect: Medewe "fell in such infirmity that he might not speak" and was "like thereby to have died" without the assistance of another surgeon.

The prosecution of negligent and inept practitioners played an important role in driving them out of the profession. For example, when Andrew le Sarazin was suffering from a fever, he approached Master John de Hexham and Master Semann, his brother, both described as medici, for help. ${ }^{69}$ Hexham contacted the local apothecary, Master William de Crek, to give his patient pills for the condition. That night, le Sarazin and his valet (who, presumably, was suffering from the same fever) "ate such a quantity of the pills" that they died of an overdose. The mayor and aldermen of London cleared the apothecary of any suspicion in the death, but both Hexham and Semann were arrested and imprisoned in Newgate; Hexham had since died. The court discovered that Semann was later released after he had paid off the gaoler; he was brought to court once again for prosecution but was eventually acquitted. Nonetheless, the reality of medical practice in later medieval England undermined the quest for quality health care. Medical practitioners often continued in their positions after serious allegations of malpractice, simply because men and women in late medieval England were so desperate for medical assistance that they had to overlook a practitioner's occasional lapse in judgement.

66 Arderne, Treatises of Fistula in Ano, xv-xviii and 23-24.

67 TNA PRO C 1/42/108 (c.1467-72).

68 TNA PRO C 1/150/8 (c.1486-93).

69 Weinbaum, ed., The London Eyre of 1276, 72-73 at 72. 
That some practitioners were the target of multiple lawsuits indicates that an allegation of incompetence did not necessarily bring business to a halt. In 1443, Matthew Rellesford had two suits brought against him in the same year. The first accusation against the London surgeon claimed that he had so poorly treated his patient for "le stone" that his condition worsened; the patient demanded $£ 20$ in damages in the mayor's court. The second accusation alleged that Rellesford had used unsuitable medicines, also exacerbating the patient's condition; perhaps having learned from the actions of the first unhappy patient, this one asked for $\mathfrak{E} 40$ in damages. ${ }^{70}$ John Barbour, the Colchester physician accused of accidentally severing a vein and thus causing the loss of his patient's arm, continued to work after the case was (apparently) settled out of court. Two years later, William Wytham brought another complaint against him, though the records fail to detail the nature of the accusation. ${ }^{71}$ Knowing the importance of reputation in the medieval world, many practitioners may have sued their clients primarily to stop the rumour mill. Certainly, some defendants went on to well-respected positions in medicine after their days in court. Marcellus de la More, mentioned above as the future royal surgeon to King Henry VIII, does not seem to have sustained any damage to his career as a result of the malpractice accusation. Henry Stratford, who appeared before the chancellor in 1433 to obtain payment from the executrix of a former patient (it is not hard to imagine why she was reluctant to pay his fee of 5 marks for curing her now dead husband), went on to become one of the founding members of the Fellowship of Surgeons just two years later. ${ }^{72}$ Nicholas Alcock, the barber-surgeon who performed miracles on Peter Benett of Eltham and sued when Benett refused to pay, also appears in a painting by Hans Holbein the Younger, entitled King Henry VIII and the Barber Surgeons, belonging to the Barbers' Company of the City of London. ${ }^{73}$ Alcock's appearance in this famed portrait, and his later position as surgeon to King Edward VI, would seem to imply that he, too, did well for himself. ${ }^{74}$

70 Talbot and Hammond, The Medical Practitioners in Medieval England, 213.

71 Jeayes, ed. \& trans., Court Rolls of the Borough of Colchester, 2:117, 118, 167, 169, 171, 173, 175, and 228.

72 TNA C 1/12/248 (for 1433); Talbot and Hammond, The Medical Practitioners in Medieval England, 84.

73 TNA PRO REQ 2/8/62; and B. Cohen, "A Tale of Two Paintings," 8.

74 Young, comp., The Annals of the Barber-Surgeons, 528. 


\section{Conclusion}

A Chancery bill surviving from the early sixteenth century acts as a valuable, if bleak, commentary on the state of medicine at the end of the Middle Ages. Richard Alyson, a London surgeon in trouble for operating outside the barber-surgeons' guild contrary to statute law, petitioned the chancellor to help him evade a $£ 120$ fine for his transgression. His bill makes it clear that the inadequate performance of guild practitioners left him no choice. ${ }^{75}$ The barber-surgeons were exploiting their monopoly on medical treatment by charging exorbitant fees for third-rate care; "for lack of cunning" and meagre experience in surgery, the barber-surgeons left their patients "in worse condition than they were when they took them in service." In dire need of assistance, many of the exploited patients, all "poor and needy people," then had to come to Alyson to be healed. Although providing his services meant breaking the law, Alyson, as a good Christian, felt compelled to intervene. Alyson unquestionably embellished his observations on the competence and business ethics of late medieval barber-surgeons in order to justify his flagrant disregard for the laws regulating medical practice. Nonetheless, his commentary underscores serious flaws in the regulation of the late medieval medical system, which are echoed in many other cases appearing in this investigation. Lacking a top-down approach to the regulation of medical care, patients were forced to assume the responsibility themselves by turning to the courts. The body of litigation that resulted from their individual mission to ensure quality medical care at a reasonable cost provides powerful insight into the nature of medieval medical practice. Although the documents rarely record the judgements of the courts, the sentences that have survived suggest that litigants found the courts responsive to these concerns. Plaintiffs regularly requested damages of impressive sums, and sometimes the courts granted them. The "lack of care and knowledge" of Richard Cheyndut, who failed to cure the injured leg of Walter, son of John del Hull, a pinner, ${ }^{76}$ led the 1377 jury to declare an award of 50 s in damages for the plaintiff. ${ }^{77}$ John Litstere of Dowsby was seeking $£ 100$ in damages after Adam Oule of Quadring, by his “imprudence and default” in healing the plaintiff's shin, left Litstere devoid of strength in that leg. ${ }^{78}$

75 TNA PRO C 1/276/13 (1504-15).

76 A "pinner" is a trapper of stray animals; thus, the patient's leg may well have been injured by being caught in a trap.

77 Thomas, ed., Calendar of Plea and Memoranda Rolls, 2:236 (for the year 1377).

78 TNA PRO KB 27/451, mm. 32d, 104; KB 27/452, m. 30d; KB 27/455, m. 92d; and KB 27/458, m. 39d (1373-75), as transcribed in Palmer, English Law in the Age of the Black Death, A7t, p. 346. 
The suits brought by patients also targeted the ineptitude of medical practitioners. Were barber-surgeons and other medical practitioners truly as ham-fisted as Alyson and the multitude of patients describe them in their petitions? The accusations of negligence in these records are often grisly and shocking; and yet, by their very nature, lawsuits involving medical practitioners offer insight into the state of medicine at its worst. The inadequacy exposed by this study lies less in the treatments administered by medical practitioners than in the nature of the contractual agreements between practitioners and their patients. The process of hiring practitioners specifically to cure a condition exposes an underlying problem in patient expectations. Medical practitioners may share in the business of saving lives with saints, but otherwise they show little resemblance; yet patients in medieval England expected them to make the lame walk and the blind see, in much the same way as they expected miraculous cures from visits to healing shrines. And when physicians failed to live up to those expectations, patients turned to the weapons they had at their disposal. However, as this study demonstrates, it was not only the patients who were persistent: many medical practitioners were equally adept at using the law to ensure they were well paid for their services. While saints had purgatory as leverage to convince their petitioners to carry out their promises, medical practitioners had something much more immediate: the law. 


\section{Bibliography}

\section{Manuscript Sources}

The National Archives Public Record Office, Kew, Surrey (TNA PRO)

Select cases from:

$\mathrm{C}$ [hancery] 1

$\mathrm{C}$ [ommon] $\mathrm{P}$ [leas] 40

$\mathrm{E}$ [xchequer] 315

K[ing's] B[ench] 27

$\mathrm{PROB}[$ ate] 11

[Court of] REQ[uests] 2

\section{Printed Primary Sources}

Arderne, John. Treatises of Fistula in Ano, Homorrhoids, and Clysters. Ed. D'Arcy Power. EETS, o.s. 139. London: Kegan Paul, Trench, Trübner, 1910.

Arnold, Morris S., ed. Select Cases of Trespass from the King's Courts, 1307-1399. Vol. 2. Selden Society 103. London: Selden Society, 1987.

Baker, J. H., and S. F. C. Milsom, eds. Sources of English Legal History: Private Law to 1750. London: Butterworths, 1986.

Gross, Charles, ed. Select Cases Concerning the Law Merchant, A.D. 1270-1638. Vol. 1, Local Courts. Selden Society 23. London: Bernard Quaritch, 1908.

Jeayes, Isaac Herbert, ed. and trans. Court Rolls of the Borough of Colchester. 3 vols. Colchester: Town Council of the Borough of Colchester, 1921-41.

Palmer, Robert C. English Law in the Age of the Black Death, 1348-1381: A Transformation of Governance and Law. Chapel Hill: Univ. of North Carolina Press, 2001.

Riley, Henry Thomas, ed. Memorials of London and London Life in the XIII ${ }^{\text {th }}, X I V^{\text {th }}$, and XV ${ }^{\text {th }}$ Centuries: Being a Series of Extracts, Local, Social, and Political From the Early Archives of the City of London, A.D. 1276-1419. London: Longmans, Green, 1868.

Stevenson, W. H., ed. Records of the Borough of Nottingham: Being a Series of Extracts from the Archives of the Corporation of Nottingham. Trans. J. Raine. Vols. 2 \& 3. London: Bernard Quaritch; Nottingham: Thomas Forman, 1882-1885.

Strachy, J., et al., eds. Rotuli Parliamentorum. Vol. 4, Tempore Henrici R. V. London: Record Commission, 1783.

Thomas, A. H., ed. Calendar of the Plea and Memoranda Rolls of the City of London. 3 vols. Cambridge: Cambridge Univ. Press, 1926-1932.

Weinbaum, Martin, ed. The London Eyre of 1276. London: London Record Society, 1976.

Young, Sidney, comp. The Annals of the Barber-Surgeons of London. London: Blades, East \& Blades, 1890. 


\section{Secondary Sources}

Auden, G. A. "The Gild of Barber Surgeons of the City of York." Proceedings of the Royal Society of Medicine 21, no. 8 (1928): 1400-1406.

Blatcher, Marjorie. The Court of King's Bench, 1450-1550: A Study in Self-Help. London: Althone Press, 1978.

Chapman, Carleton B. "Stratton vs. Swanlond: The Fourteenth-Century Ancestor of the Law of Malpractice." The Pharos: of Alpha Omega Alpha Honor Medical Society 45, no. 4 (1982): 20-24.

Cohen, Bertram. "A Tale of Two Paintings." Annals of the Royal College of Surgeons of England 64 (1982): 3-12.

Cohen, Esther. "The Expression of Pain in the Later Middle Ages: Deliverance, Acceptance and Infamy." In Bodily Extremities: Preoccupations with the Human Body in Early Modern European Culture, edited by Florike Egmond and Robert Zwijnenberg, 195-219. Aldershot: Ashgate, 2003.

Cosman, Madeleine Pelner. "Medieval Medical Malpractice: The Dicta and the Dockets." Bulletin of the New York Academy of Medicine 49, no. 1 (1973): 22-47.

Du Cange, Charles du Fresne, et al., eds. Glossarium mediae et infimae latinitatis. Niort: L. Favre, 1883-1887.

Dyer, Christopher. Standards of Living in the Later Middle Ages: Social Change in England c.1200-1520. Rev. ed. Cambridge: Cambridge Univ. Press, 1998.

Edwards, William. The Early History of the North Riding. London: A. Brown, 1924.

Finch, Andrew. "The Disciplining of the Laity in Late Medieval Normandy." French History 10, no. 2 (1996): 163-81.

Freedman, Paul. Out of the East: Spices and the Medieval Imagination. New Haven, Conn.: Yale Univ. Press, 2008.

French, Roger. Medicine before Science: The Rational and Learned Doctor from the Middle Ages to the Enlightenment. Cambridge: Cambridge Univ. Press, 2003.

Frey, Albert R. Dictionary of Numismatic Names. New York: American Numismatic Society, 1947.

Harding, Alan. Medieval Law and the Foundations of the State. Oxford: Oxford Univ. Press, 2001.

Harrison, Mark. Disease and the Modern World: 1500 to the Present Day. Cambridge, UK, \& Malden, Mass.: Polity, 2004.

Hastings, Margaret. The Court of Common Pleas in Fifteenth-Century England: A Study of Legal Administration and Procedure. Ithaca: Cornell Univ. Press, 1947.

McVaugh, Michael. "Cataracts and Hernias: Aspects of Surgical Practice in the Fourteenth Century." Medical History 45, no. 3 (2001): 319-40.

Nutton, Vivian. "Medicine in Medieval Western Europe, 1000-1500.” In The Western Medical Tradition: 800 BC to AD 1800, edited by Lawrence I. Conrad et al., 139-205. Cambridge: Cambridge Univ. Press, 1995. 
Oxford English Dictionary: OED Online. June 2012. Oxford Univ. Press. Available at <http:// www.oed.com> (by subscription). Accessed 1 July 2012.

Pelling, Margaret. Medical Conflicts in Early Modern London: Patronage, Physicians, and Irregular Practitioners, 1550-1640. Oxford: Clarendon Press, 2003.

Rawcliffe, Carole. Leprosy in Medieval England. Woodbridge: Boydell Press, 2006.

-. Medicine and Society in Later Medieval England. Stroud, UK: Alan Sutton, 1995; London: Sandpiper, 1999.

Riddle, John M. "Contraception and Early Abortion in the Middle Ages." In Handbook of Medieval Sexuality, edited by Vern L. Bullough and James A. Brundage, 261-77. New York: Garland, 1996.

Stell, Philip. Medical Practice in Medieval York. York: Borthwick Institute of Historical Research, 1996.

Talbot, C. H., and E. A. Hammond. The Medical Practitioners in Medieval England: A Biographical Register. London: Wellcome Historical Medical Library, 1965.

Theilmann, J. M. “The Regulation of Public Health in Late Medieval England.” In The Age of Richard II, edited by James L. Gillespie, 205-23. Stroud, UK: Alan Sutton; New York: St. Martin's Press, 1997.

Tucker, P. "The Early History of the Court of Chancery: A Comparative Study." English Historical Review 115 (2000): 791-811.

Wallis, Faith. "Signs and Senses: Diagnosis and Prognosis in Early Medieval Pulse and Urine Texts." Social History of Medicine 13, no. 2 (2000): 265-78. 